\title{
ČLÁNKY
}

\section{Trestní odpovědnost při hospodaření $s$ veřejným majetkem a výkon pravomoci úřední osoby}

\section{Criminal Liability for the Misappropriation of Public Property in the Context of Exercise of Official Authority}

\author{
František Púry ${ }^{*}$, Martin Richter ${ }^{* *}$
}

\begin{abstract}
Abstrakt
Př́spèvek se zabývá trestni odpovédností za nikoli rádné hospodareni s majetkem státu nebo územnich samosprávných celk.ù osobami, které jsou v postaveni úredni osoby. Zejména spoukazem na situaci v obecní

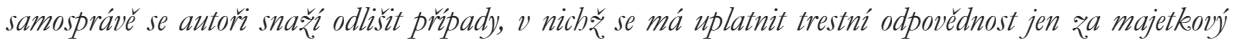
trestny čin, a prǐpady, kde jde vedle toho nebo jen samostatně o trestný čin zneurití pravomoci úredni osoby. Své úvaby ilustrují i něketerými roz̧odnutimi Nejvyššriho soudu.
\end{abstract}

\section{Klíčová slova}

Úredni osoba; zneư̌ití pravomoci üredni osoby; trestný čin; hospodařeni s majetkem; veřejný majetek; obec; územni samosprávný celek; výkon územni samosprávy.

\section{Abstract}

The article deals with criminal liability for improper disposition of public property by official person. With particular reference to the situation in the municipal government, authors try to distinguish the cases in which should be applied criminal liability solely for property offense and cases where official person should bear liability concurrently for or separately for criminal offense of abuse of power. Their reasoning is illustrated by some Supreme Court decisions.

\section{Keywords}

Official Person; Abuse of Power; Criminal Offense; Disposition of Property; Public Property; Municipal Unit; Local Government.

\footnotetext{
* JUDr. František Púry, Ph.D., předseda trestního kolegia, Nejvyšší soud České republiky / chairman, Criminal Division, Supreme Court of the Czech Republic / E-mail: frantisek.pury@nsoud.cz

** Mgr. Martin Richter, doktorand, Právnická fakulta, Univerzita Karlova, Praha; Ministerstvo spravedlnosti České republiky, pověren řízením odboru insolvenčního / Ph.D. student, Faculty of Law, Charles University, Prague, Czech Republic; Ministry of Justice of the Czech Republic / E-mail: mrichter@msp.justice.cz / ORCID: orcid.org/0000-0003-0631-6260
} 


\section{Úvodem}

V souvislosti s výkonem veřejné moci a s uskutečňováním poslání orgánů státu a územních samosprávných celků je zřejmé, že tyto subjekty hospodaří s určitým majetkovým substrátem, který je ekonomickým základem jejich činnosti. Jde zejména o nakládání s penězi ze státního rozpočtu, z rozpočtů územních samosprávných celků a z dalších veřejných zdrojů, dispozice s majetkovými hodnotami ve vlastnictví státu a územních samosprávných celků a s jiným majetkem svěřeným k obhospodařování. Pro zjednodušení budeme všechny tyto majetkové hodnoty dále označovat jako „veřejný majetek“, abychom tím vyjádřili jeho základní povahu, tj. že pochází z veřejných (nikoli soukromých) zdrojů, že není ve vlastnictví soukromých fyzických nebo právnických osob a že hospodaření s ním je ve veřejném zájmu podrobeno určitým pravidlům a omezením.

S tímto veřejným majetkem činí dispozice celá řada fyzických osob, z nichž některé jako představitelé, funkcionári či zaměstnanci orgánů státu nebo územních samosprávných celků - mohou, ale nemusí mít postavení úředních osob ve smyslu $\ 127$ zákona č. 40/2009 Sb., trestního zákoníku, ve znění pozdějších předpisů (dále ve zkratce „TrZ“). Ve svém př́spěvku bychom proto chtěli věnovat pozornost otázce, kdy lze uvažovat o tom, že nedodržení pravidel řádného hospodaření s veřejným majetkem nebo postup a rozhodování s tím související může znamenat spáchání nejen trestného činu proti majetku nebo trestného činu hospodářského, ale též (nebo jen) trestného činu zneužití pravomoci úřední osoby, a to u těch fyzických osob, které mají postavení úřední osoby.

V zájmu dalšího zjednodušení a s ohledem na dosavadní soudní praxi se soustředíme na tu část výkonu veřejné moci, kterou označujeme jako územní samosprávu, a to konkrétně na úrovni měst a obcí, prúčemž pojmem „obec“ budeme rozumět i město nebo městys. Územním samosprávným celkem je pak kraj, hlavní město Praha a obec a pro jejich souhrnné označení používáme i zkratku „ÚSC“.

\section{1 Úřední osoba a výkon její pravomoci}

Okruh osob, které se pro účely trestní odpovědnosti považují za úřední osoby, vyplývá z ustanovení $\ 127$ odst. 1 , 3 a $\ 334$ odst. 2 TrZ. V souvislosti s činností ÚSC má význam zejména ustanovení \127 odst. 1 písm. d) TrZ, podle něhož je úřední osobou, pokud plní úkoly státu nebo společnosti a použivá při tom svěřené pravomoci pro plnění těchto úkolů, též člen zastupitelstva nebo odpovědný úředník územní samosprávy, orgánu státní správy nebo jiného orgánu veřejné moci. Pro účely tohoto př́íspěvku odhlížíme od skutečnosti, že za obdobných podmínek je úřední osobou podle $\$ 127$ odst. 1 písm. e) TrZ i strážník obecní policie.

V této souvislosti je vhodné príipomenout, že z postavení úrední osoby vyplývá jak zvýšená trestní odpovědnost, a to zejména za trestný čin zneužití pravomoci úřední osoby podle $₫ 329 \operatorname{TrZ}$, maření úkolu úřrední osoby z nedbalosti podle $₫ 330 \operatorname{TrZ}$ nebo príjetí 
úplatku podle $\int 331$ odst. 1, odst. 2, odst. 3 písm. b), odst. 4 písm. b) TrZ, tak i zvýšená ochrana před některými útoky např. v podobě trestných činů násilí proti úřední osobě podle \325 TrZ, vyhrožování s cílem působit na úřední osobu podle \326 TrZ a vraždy podle $\int 140$ odst. 1 , odst. 2 , odst. 3 písm. d) TrZ.

K trestní odpovědnosti a ochraně úřední osoby se podle jednotlivých ustanovení trestního zákona vyžaduje, aby trestný čin byl spáchán v souvislosti s její pravomocí a odpovědností ( $\int 127$ odst. 2 TrZ). Charakteristickým znakem a nezbytným předpokladem ke zvýšené trestněprávní odpovědnosti i ochraně úřední osoby je tedy výkon její pravomoci. Jím lze zjednodušeně rozumět zejména vrchnostenské rozhodování o právech a povinnostech jiných osob.

Pravomoc obecně spočívá v oprávnění orgánu (úřední osoby) vykonávat veřejnou moc, přičemž veřejnou mocí se rozumí taková moc, která autoritativně rozhoduje o právech a povinnostech jiných osob (subjektů), at' již př́ímo nebo zprostředkovaně. Subjekt, o jehož právech nebo povinnostech se rozhoduje, není v rovnoprávném postavení s rozhodujícím orgánem (úřední osobou) a obsah rozhodnutí tohoto orgánu nezávisí na vưli takového subjektu. ${ }^{1}$ I když za výkon pravomoci nelze považovat jen rozhodování o právech a povinnostech fyzických i právnických osob, v pojmu pravomoci je vždy obsažen prvek moci a prvek rozhodování. ${ }^{2}$ Osoba, která nedisponuje rozhodovací pravomocí nebo pravomocí bezprostředně související s takovou rozhodovací pravomocí, nemůže být úřední osobou. ${ }^{3}$ Úřední osobou je však nejen osoba, která přímo vydává nebo učiní konkrétní rozhodnutí, ale i osoba, která věcně připravuje takové rozhodnutí za podmínky, že bez této přípravy by dané rozhodnutí nemohlo být učiněno, ${ }^{4}$ anebo která takové rozhodnutí vykonává, tedy zabezpečuje výkon rozhodnutí.

V souvislosti s hospodařením orgánů státu nebo ÚSC s veřejným majetkem ovšem př́islušné fyzické osoby, které jinak mohou mít postavení úřední osoby, vstupují do celé řady různých vztahů, které se vyznačují rovnoprávným postavením jejich účastníků a v nichž se neuplatňuje prvek moci a vrchnostenského rozhodování.

\section{Postavení státu, krajů a obcí v majetkových vztazích}

Jak vyplývá z ustanovení \ 21 zákona č. 89/2012 Sb., občanského zákoníku, ve znění zákona č. 460/2016 Sb. (dále ve zkratce „ObčZ“), \ 1 odst. 2 zákona č. 129/2000 Sb.,

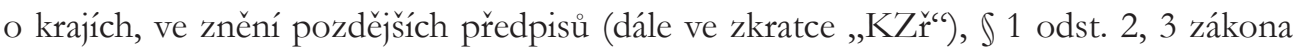

1 Viz usnesení Ústavního soudu ze dne 25. 11. 1993, sp. zn. II. ÚS 75/93, publikované pod č. 3 ve svazku 2 Sbírky nálezů a usnesení Ústavního soudu.

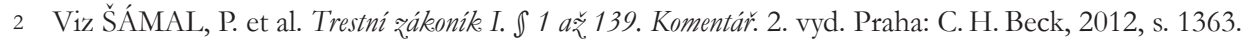

3 Viz přiměřeně rozhodnutí pod č. 17/1967 Sb. rozh. tr. v odůvodnění.

4 Viz též nález Ústavního soudu ze dne 30. 3. 2000, sp. zn. III. ÚS 371/99, publikovaný pod č. 49 ve svazku 17 Sbírky nálezů a usnesení Ústavního soudu. 
č. 131/2000 Sb., o hlavním městě Praze, ve znění pozdějších předpisů (dále ve zkratce „ZHMP“), a \ 2 odst. 1 zákona č. 128/2000 Sb., o obcích, ve znění pozdějších předpisů (dále ve zkratce „OZřّ), stát, kraje, hlavní město Praha a obce se považují v právních vztazích za právnické osoby a mají samostatnou právní osobnost, protože vystupují v právních vztazích svým jménem a nesou odpovědnost vyplývající z těchto vztahů.

V uvedených vztazích při provádění určitých majetkových dispozic s veřejným majetkem pak stát (jeho organizační složky) a ÚSC vystupují v zásadě v rovnoprávném postavení vůči dalším účastníkům takových vztahů, v nichž nemohou uplatňovat svou vrchnostenskou moc, která byla vymezena výše a která je charakteristická pro výkon pravomoci úřední osoby. Majetková dispozice s veřejným majetkem zde ovšem může být více či méně vzdáleným důsledkem určitého mocenského rozhodnutí orgánu státu nebo ÚSC, tedy i úřední osoby. ${ }^{5}$

\section{Obecně k možnostem trestního postihu úřední osoby}

V souvislosti s hospodařením úřední osoby s veřejným majetkem můžeme při vyvozování její trestní odpovědnosti $\mathrm{v}$ př́ípadě porušení stanovených pravidel a povinností rozlišovat tři základní situace odůvodňující tyto možnosti trestního postihu:

a) za souběh trestného činu spáchaného v postavení úřední osoby, zejména za zneužití pravomoci podle $\int 329$ TrZ, s některým z úmyslných trestných činů hospodářských nebo proti majetku, typicky např. se zpronevěrou podle $\int 206 \operatorname{Tr} Z$ nebo s porušením povinnosti při správě cizího majetku podle \220 TrZ. Tak tomu bude tehdy, jestliže je třeba vyjádřit obě stránky spáchané trestné činnosti, tj. jak onu „veřejně mocenskou“ spočívající v nikoli řádném výkonu pravomoci úřední osoby, tak také hospodářskou či majetkovou, spočivající v nikoli řádném hospodaření s veřejným majetkem a $\mathrm{v}$ případném způsobení škody na něm či opatření neoprávněného prospěchu;

b) jen za trestný čin proti majetku nebo hospodářský, a to spáchaný úmyslně nebo z nedbalosti, např. za zjednání výhody při zadání veřejné zakázky, při veřejné soutěži a veřejné dražbě podle $\int 256 \operatorname{Tr} Z$, za zpronevěru podle $\int 206 \operatorname{Tr} Z$ nebo za porušení povinnosti při správě cizího majetku podle \220 nebo \ $221 \mathrm{Tr} Z$, pokud zde není určitá souvislost s výkonem pravomoci úřední osoby, ale byl zasažen jen hospodár̆ský či majetkový zájem;

c) jen za trestný čin spáchaný v postavení úřední osoby, typicky za zneužití pravomoci podle $\int 329$ TrZ nebo za maření úkolu úřední osoby z nedbalosti podle $\int 330 \mathrm{Tr} Z$, poprrípadě za přijetí úplatku podle $\int 331$ TrZ, není-li zde majetkový nebo hospodářský aspekt trestné činnosti, jak je tomu v předchozích př́padech.

5 Opačný názor viz v př́spěvku ONDRUŠ, R. Pracovníci veřejné správy a státních orgánů a postaveni veřejného činitele. Trestní právo, 2000, č. 4, s. 19; a určité pochyby i v př́spěvku ŽĎÁRSKÝ, Z. Trestní odpovědnost úřední osoby - téma vskutku aktuální. Státní zuastupitelství, 2013, č. 5, s. 43. 


\section{Některé prŕiklady ze soudní praxe}

V soudní praxi se $\mathrm{v}$ souvislosti s trestním postihem určitých fyzických osob, jež měly postavení úředních osob, za jejich nikoli řádné hospodaření s veřejným majetkem vyskytují různé př́pady, k nimž dochází zejména při výkonu územní samosprávy, a můžeme je demonstrovat na rozhodovací praxi senátů trestního kolegia Nejvyššího soudu.

\subsection{Tajemník městského úřadu - zneužití pravomoci a ovlivnění veřejné zakázky}

Tak např. v usnesení Nejvyššího soudu ze dne 11. 5. 2016, sp. zn. 5 Tdo 279/2016, ${ }^{6}$ byl učiněn především výchozí závěr, že k vyvození odpovědnosti za trestný čin zneužití pravomoci úřední osoby podle $₫ 329 \mathrm{Tr} Z$ nepostačuje jen obecně postavení toho, kdo má být pachatelem, jako úrúední osoby, ale je třeba, aby $\mathrm{v}$ rámci trestně postižitelného jednání vykonával pravomoc, kterou by mohl autoritativně a efektivně ovlivnit činnost jiného subjektu. K tomu může dojít třeba v souvislosti s podílem pachatele na rozhodovacím procesu při zadávání veřejných zakázek.

V další části téhož rozhodnutí se Nejvyšší soud zabýval mimo jiné i možností zneužití pravomoci úřední osoby tajemníkem městského úřadu při rozhodování o určitých majetkových dispozicích. K tomu Nejvyšší soud uvedl, že obviněný jako tajemník městského úřadu mohl porušit ustanovení \16 odst. 1 písm. f) zákona č. 312/2002 Sb., o úřednících územních samosprávných celků a o změně některých zákonů, ve znění pozděǰ̌ích předpisů, podle něhož je úředník územního samosprávného celku (kterým je i tajemník městského úradu - viz $\ 2$ odst. 7 citovaného zákona) povinen jednat a rozhodovat nestranně bez ohledu na své přesvědčení a zdržet se při výkonu práce všeho, co by mohlo ohrozit důvěru v nestrannost rozhodování. Přitom podle zákona č. 128/2000 Sb., ve znění pozdějších předpisů (obecního zrrízenî), lze v určitých prípadech zahrnout pod pojem „pravomoc" též rozhodování v oblasti hospodaření s majetkem územního samosprávného celku ( $\$ 38$ a násl., \85 OZř), ačkoliv obecní zrízení výslovně nestanoví žádná práva a povinnosti tajemníka obecního (městského) úřadu při nakládání $\mathrm{s}$ majetkem obce (města). Tajemník však může rozhodovat o tomto majetku v souvislosti s plněním úkolů uvedených v ustanovení $\$ 110$ odst. 4 OŽr. ${ }^{7}$ Obviněný jako tajemník městského úradu se tedy mohl dopustit trestného činu tím, že záměrně předložil vadný (resp. nehospodárný) návrh usnesení radě města k přijetí, resp. hlasování. Takové předložení by pak mohlo být samostatnou trestněprávně relevantní príčcinou, přičemž následný vývoj prýćinné souvislosti vedoucí ke škodlivému následku by musel být zahrnut zaviněním obviněného

6 Text tohoto usnesení, stejně jako dalších rozhodnutí Nejvyššího soudu, na něž v př́íspěvku odkazujeme, je dostupný na www.nsoud.cz

7 K tomu viz též usnesení Nejvyššího soudu ze dne 11. 8. 2010, sp. zn. 5 Tdo 733/2010. 
alespoň v hrubých rysech, a to v prrípadě, jestliže obviněný počítal s tím, že hlasujícím členům rady zůstane protiprávnost, nehospodárnost či jiná vada jeho návrhu skryta.

Ve shora citovaném rozhodnutí pak Nejvyšší soud podrobně odůvodnil, že v daném př́padě obviněný jako tajemník městského úřadu naplnil i skutkovou podstatu trestného činu zjednání výhody při zadání veřejné zakázky podle \256 odst. 1 TrZ. Toho se měl dopustit tím, že jako tajemník Městského úřadu Z., člen komise pro otevírání obálek ve veřejných zakázkách na služby v objemu do 2000000 Kč a řešitel veřejné zakázky „Auto na rozvoz obědů pro C.“, v které byl schválen jako vítěz uchazeč L. S. autoprodejna, poté, co vozidla, jejichž nákup byl předmětem veřejné zakázky, odmítlo C. s tím, že nesplňují požadavek na objem nákladového prostoru, v rozporu se zásadami podle \6 zákona č. 137/2006 Sb., o veřejných zakázkách, ve znění pozdějších předpisů, a čl. III odst. 4 Zásad pro zadávání veřejných zakázek č. 3/2007 zadavatele - města Z. instruoval L. S. a umožnil mu dodatečně předložit nabídku na jiná vozidla namísto pưvodní nabídky, která již odpovídala stanovenému požadavku na objem nákladového prostoru, ale za výrazně vyšší cenu (vyšší než byla nabídka druhého uchazeče), a to aniž by bylo vypsáno nové výběrové řízení. Poté obviněný předložil Radě města Z. ke schválení návrh na revokaci části usnesení, jímž byl schválen výsledek výběrového řízení pro původní nevyhovující vozidla, s tím, že došlo k chybě, když byla schválena dvě vozidla, ale v zápise bylo uvedeno jen jedno, aniž by Radu města Z. informoval, že došlo i ke změně typu a ceny vozidla. Následně obviněný dne 27. 4. 2010 telefonicky sdělil L. S., že může začít jednat s C., a instruoval ho, aby mu dodatečně písemně dodal nabídku na nové typy vozidel, které vůbec nebyly předmětem původní nabídky. Tato vozidla byla následně objednána, dodána a jejich cena uhrazena.

Obviněný tajemník městského úřadu tedy i podle názoru Nejvyššího soudu porušil své povinnosti vztahující se k př́pravě podkladů pro rozhodnutí Rady města Z., protože neoprávněně zasáhl do zmíněného zadávacího řízení v rozporu s ustanovením \ 6 zákona č. 137/2006 Sb., o veřejných zakázkách, ve znění pozdějších předpisů, i se Zásadami pro zadávání veřejných zakázek č. 3/2007 zadavatele - města Z. Přitom obviněný manipuloval s podklady, které předkládal Radě města Z., a jejím členům nesdělil, že revokujícím usnesením se mění nejen počet vozidel, ale i typ vozidel a jejich cena, která byla v porovnání s cenou druhého uchazeče vyšší. Obviněný tím současně zajistil uchazeči L. S. výhodnější podmínky, když mu na základě telefonického rozhovoru umožnil učinit dodatečnou nabídku, která již vyhovovala zadání veřejné zakázky, ovšem cenově byla méně výhodná než nabídka konkurenčního dodavatele.

\subsection{Starosta obce - pochybnosti o zneužití pravomoci a porušení povinnosti při správě cizího majetku}

Pokud jde o veřejné zakázky, poněkud jinou situací se zabýval Nejvyšší soud v usnesení ze dne 26. 2. 2014, sp.zn. 5 Tdo 77/2014, které se týká věci, v níž byl starosta 
obce odsouzen za trestné činy zneužití pravomoci úřední osoby podle \329 odst. 1 písm. a), b), odst. 2 písm. a) TrZ a porušení povinnosti při správě cizího majetku podle \220 odst. 1, odst. 2 písm. a), b) TrZ zčásti spáchané v pokusu podle \21 odst. $1 \operatorname{Tr} Z$. Tuto trestnou činnost měl spáchat - stručně vyjádřeno - tím, že jako starosta obce B. bez vědomí a souhlasu zastupitelstva obce B., bez vědomí a souhlasu rady obce B., v rozporu s rozpočtem obce $B$. na př́slušný rok a v rozporu s ustanovením $₫ 102$ odst. 2 písm. a) OŽr svévolně uzavřel s př́íslušnými podnikateli smlouvy o dílo, jejichž předmětem byly stavební a rekonstrukční práce na majetku obce B., přičemž cena za provedení díla byla ve všech třech případech vyšší, než jaká byla v daném místě a čase obvyklá. Tím měl obviněný porušit ustanovení \ 102 odst. 3 OŽr a ustanovení \ 6 zákona č. 137/2006 Sb., o veřejných zakázkách, ve znění pozdějších předpisů, a způsobit škodu v celkové výši asi 1,7 mil. Kč, která v této výši hrozila a zčásti (asi ve výši 300000 Kč) i vznikla.

Nejvyšší soud však v tomto prrípadě zpochybnil naplnění subjektivní stránky obou trestných činů, jimiž byl obviněný starosta obce uznán vinným. K tomu mimo jiné uvedl, že pachatelem trestného činu zneužití pravomoci úřední osoby podle \329 odst. 1 TrZ sice může být i starosta obce, jehož lze považovat za úřední osobu ve smyslu \127 odst. 1 písm. d) TrZ. K naplnění subjektivní stránky skutkové podstaty tohoto trestného činu však nestačí jen úmyslné jednání pachatele, ale vyžaduje se jeho pohnutka spočívající v úmyslu způsobit jinému škodu nebo jinou závažnou újmu anebo opatřit sobě nebo jinému neoprávněný prospěch. Takovou pohnutku ovšem nezakládá samotné skutkové zjištění, že starosta obce uzavřel smlouvy na dodávky stavebních (rekonstrukčních) prací za ceny, které převyšovaly ceny v daném místě a čase obvyklé, pokud byly dané práce na majetku obce skutečně provedeny, resp. bylo nutné je provést, zakázku na dodávku prací a platbu za ně získaly osoby, jež nebyly v žádném vztahu ke starostovi, a ani jiné okolnosti nesvědčily o záměrném zvýhodnění určitých osob starostou či o jeho snaze poškodit obec. Z popisu skutku přitom není patrné, že by obviněný již v době uzavírání smluv o dílo musel být alespoň srozuměn s předražením ceny jednotlivých děl a s možností jejich provedení za podstatně nižší ceny, než na jaké přistoupil v uzavřených smlouvách. Pro takové zjištění pak není v rozhodnutích soudů nižších stupňů ani žádný skutkový podklad, z něhož by jednoznačně vyplýval záměr obviněného zaplatit z rozpočtu obce vyšší částku, ačkoli byla dosažitelná nižší cena za provedení díla. Navíc, soud prvního stupně zde nesprávně argumentuje porušením ustanovení $\int 102$ odst. 2 písm. a), odst. 3 OŽr, která se týkají rady obce, a nikoli jejího starosty, jímž byl obviněný. Obviněný si sice dostatečně neověril dosažitelnou cenu obdobných stavebních prací na trhu, ačkoli mu v tom nebránily žádné překážky, nicméně právě tato okolnost svědčí o tom, že nejednal prímo se znalostí všech rozhodných skutečností, které by odůvodňovaly závěr o existenci jeho pohnutky vyžadované u zločinu zneužití pravomoci úřední osoby. Odvolací soud pak v odůvodnění svého usnesení dokonce konstatuje, že obviněný jako starosta vykonal pro obec B. hodně práce a že smlouvy na provedení jednotlivých děl v zásadě měly být uzavřeny, protože bylo nutné provést dané práce. 
Nejvyšší soud zde uzavřel, že z popisu rozhodných skutkových okolností není zřejmé, že obviněný jako starosta obce jednal skutečně v úmyslu způsobit škodu na jím spravovaném majetku obce a že nešlo jen o jeho nedbalost spočívající v nevynaložení dostatečného úsilí k dosažení takové ceny za dílo, která by byla příznivější pro obec. Zmíněný úmysl by bylo možno dovozovat mimo jiné i z toho, kdyby např. obviněný záměrně nerespektoval pravomoc zastupitelstva obce nebo její rady, resp. kdyby účelově obcházel jejich rozhodnutí a nahrazoval je vlastními. Proto Nejvyšší soud zrušil odsuzující rozhodnutí obou soudů nižších stupňů a přikázal soudu prvního stupně nové projednání a rozhodnutí věci.

\subsection{Starostka obce - nepochybné zneužití pravomoci a porušení povinnosti při správě cizího majetku}

Na rozdíl od předchozího případu v této věci Nejvyšší soud usnesením ze dne 20. 5. 2015, sp. zn. 5 Tdo 492/2015, ${ }^{8}$ odmítl dovolání obviněné starostky podané proti odsuzujícím rozhodnutím soudů nižších stupňů, jimiž byla odsouzena mimo jiné za trestné činy porušování povinnosti při správě cizího majetku podle \ 255 odst. 1, odst. 3 zákona č. 140/1961 Sb., trestního zákona, ve znění pozdějších předpisů (dále ve zkratce „tr. zák.“; nyní by šlo o porušení povinnosti při správě cizího majetku podle $\ 220$ odst. 1, 3 TrZ), a zneužívání pravomoci veřejného činitele podle $\int 158$ odst. 1 písm. a), odst. 2 písm. c) tr. zák. [nyní by šlo o zneužití pravomoci úřední osoby podle 329 odst. 1 písm. a), odst. 2 písm. f) TrZ].

Uvedené trestné činy spáchala obviněná starostka ve stručnosti tím, že za účelem neoprávněného získání prostorů pro vlastní bydlení v budově obecního úřadu uzavřela bez projednání a schválení tohoto úkonu zastupitelstvem obce, a tedy v rozporu s ustanovením $\int 85$ písm. a) OŽr, jménem obce smlouvu o dílo s obchodní společností jako zhotovitelem díla, jejímž předmětem byla výstavba bytové jednotky, přestože si byla vědoma skutečnosti, že obec nemá a nebude mít v termínu stanoveném pro dokončení díla a jeho předání bez vad a nedodělků dostatek finančních prostředků na uhrazení ceny díla ve výši asi 2,5 mil. Kč, v důsledku čehož bude zhotovitel v souladu s obsahem smlouvy jednostranně nevýhodné pro obec oprávněn požadovat úhradu smluvního úroku z prodlení s placením faktur, který byl ve smlouvě stanoven ve zjevně nepřiměřené výši ve prospěch zhotovitele na $10 \%$ z dlužné částky týdně, zatímco pro př́pad nedodržení termínu zhotovení díla byla zhotoviteli stanovena smluvní pokuta ve výši $0,01 \%$ z ceny díla denně (tedy $0,07 \%$ týdně). Následně obviněná starostka $\mathrm{v}$ rozporu s ustanovením \ 115 zákona č. 183/2006 Sb., o územním plánování a stavebním řádu, ve znění pozdějších předpisů, umožnila zhotoviteli zahájení výstavby bytové jednotky bez rozhodnutí stavebního úřadu o umístění a povolení stavby, které bylo vydáno

8 Ústavní stížnost podanou proti citovanému rozhodnutí Nejvyššího soudu odmítl Ústavní soud svým usnesením ze dne 19. 1. 2016, sp. zn. II. ÚS 3454/15, jako návrh zjevně neopodstatněný. 
až dodatečně. Poté, aniž by zhotovitelem bylo dílo řádně dokončeno a provedené práce rádně fakturovány, obviněná podepsala dohodu o zaplacení uznaného dluhu, kde uznala dluh obce jako objednatele ve výši celé smluvené ceny díla asi 2,5 mil. Kč, a následně převzala od zhotovitele dílo podle zápisu jako dokončené bez vad a nedodělků, které by bránily jeho užívání, přestože věděla, že ve skutečnosti nebylo dílo dokončeno a zjevné vady a nedodělky brání jeho řádnému užívání, když souhlas ke kolaudaci stavby byl udělen až dodatečně. Tím obviněná porušila ustanovení \38 odst. 1, 2 OŽr ukládající jí využívat majetek obce účelně a hospodárně v souladu s jejími zájmy a chránit jej před zneužitím, ve spojení s ustanovením \301 písm. d) zákona č. 262/2006 Sb., zákoníku práce, ve znění pozdějších předpisů, podle něhož měla řádně hospodařit s prostředky svěřenými jí zaměstnavatelem a stř̌žit a ochraňovat majetek zaměstnavatele před poškozením, ztrátou, zničením a zneužitím.

Obviněná dále uzavřela se zhotovitelem díla pro obec jednostranně nevýhodnou rozhodčí doložku, podle které veškeré spory ze smlouvy o dílo a spory ze vztahů s ní souvisejících bude rozhodovat rozhodce, jehož si jmenuje věřitel, umožnila zhotoviteli díla následné vymáhání ceny díla a smluvních úroků z prodlení v rozhodčích řízeních, v jejichž průběhu opětovně uznávala nároky zhotovitele, přestože věděla, že dílo nebylo řádně dokončeno, a naopak sama v rozporu s ustanovením \38 odst. 7 OŽr neuplatňovala jménem obce nároky ze smlouvy o dílo, vyplývající z jeho předání v nikoli rádném stavu, ani nevyužila řádně a včas opravných prostředků proti rozhodnutím v rozhodčím a exekučním řízení. Tím obviněná způsobila poškozené obci škodu ve výši asi 13,5 mil. Kč.

Nejvyšší soud zde zdůraznil, že obviněná vystupovala jako starostka obce v postavení veřejného činitele [〕 89 odst. 9 tr. zák.; nyní jde o úřední osobu ve smyslu \ 127 odst. 1 písm. d) TrZ] a byla rovněž povinna znát obsah svých pravomocí vyplývajících především ze zákona o obcích a dodržovat je ve své činnosti. Jak je žrejmé z rozhodných skutkových zjištění, ačkoli př́islušné stavební práce na objektu v majetku obce byly provedeny nikoli řádně a včas, obviněná jednající za obec v postavení starostky uznala závazek zhotovitele díla a dokonce s ním sjednala i nevýhodnou rozhodčí doložku, přestože věděla, že dílo nebylo řádně dokončeno, čímž jednoznačně znevýhodnila obec, ačkoli měla naopak hájit její zejména majetkové zájmy. Přitom jednala s cílem vytvořit v obci prostor pro bydlení, ovšem jen pro sebe, protože podala žádost o jeho přidělení. Obviněná tak zneužila postavení veřejného činitele k prosazení osobních zájmů a bez ohledu na majetkové zájmy obce, které měla naopak chránit, takže si počínala nehospodárně ke škodě této veřejnoprávní korporace. Ze shora citovaného popisu skutku je dále patrné, že obviněná již v době uzavírání smlouvy o dílo musela být alespoň srozuměna s jednostranně nevýhodnými smluvními podmínkami, navíc za situace, kdy umožnila zhotoviteli zahájení stavby bez prríslušného rozhodnutí stavebního úřadu. Právní úkony, které se týkaly především uznání uplatněných majetkových nároků zhotovitele díla, pak nevyžadovaly žádné zvláštní odborné znalosti a jejich nevýhodnost pro obec musela být 
obviněné zřejmá, pokud by jednala i jen s běžnou péčí a opatrností. Z toho jednoznačně vyplývá záměr obviněné vytvořit si podmínky pro získání obecního bydlení bez ohledu na priměřenost ceny díla zaplacené $z$ rozpočtu obce a na další nepříznivé majetkové důsledky pro obec. Obviněná nezajistila dostatečně právní rámec stavebních prací a počínala si popsaným způsobem se znalostí všech rozhodných skutečností. O jejím záměru obohatit se na úkor majetku obce ostatně svědčí i skutečnost, že smlouvu o dílo nevýhodnou pro obec uzavřela se zhotovitelem bez projednání a schválení tohoto úkonu zastupitelstvem obce.

\section{4 Členové zastupitelstva města - porušení povinnosti při správě cizího majetku z nedbalosti}

Pouze možnou majetkovou trestnou činností, bez případného trestněprávního vyjádření toho, že jde o úřední osoby, se zabýval Nejvyšší soud v usnesení ze dne 19. 12. 2012, sp. zn. 5 Tdo 827/2012, které bylo uveřejněno jako rozhodnutí pod č. 2/2014 Sb. rozh. tr. V této trestní věci bylo obviněno celkem 23 členů zastupitelstva jednoho statutárního města, kteři na zasedání zastupitelstva města schválili prodej nemovitého majetku města (dvou pozemků) za cenu ve výši asi 1,5 mil. Kč, ačkoli dosažitelná cena v daném místě a čase byla ve výši asi 5 mil. Kč. Tím měli z nedbalosti způsobit škodu ve výši asi 3,5 mil. Kč, a spáchat tak trestný čin porušování povinnosti při správě cizího majetku podle $\int 255$ a odst. 1 tr. zák., resp. trestný čin porušení povinnosti při správě cizího majetku z nedbalosti podle \ 221 odst. 1 TrZ (skutek byl totiž spáchán ještě za účinnosti trestního zákona, ale posuzován už byl za účinnosti trestního zákoníku).

Ponecháme-li stranou otázku časové působnosti trestních zákonů, Nejvyšší soud zde učinil několik zásadních závěrů. Tak především, jestliže obvinění jako členové zastupitelstva obce (města) rozhodli na zasedání tohoto vrcholného orgánu obce o schválení prodeje nemovitého majetku obce za podstatně nižší kupní cenu, než jaká byla v daném místě a čase dosažitelná (např. za částku ve výši asi 1,5 mil. Kč, ačkoli dosažitelná cena byla asi 5 mil. Kč), lze v tomto jednání spatřovat porušení povinnosti při opatrování nebo správě cizího majetku vyplývající zejména z ustanovení \39 odst. 2, \84 a \85 písm. a) OŽr. Přitom význam rozhodování členů zastupitelstva obce o prodeji nemovitého majetku obce a jejich postavení odůvodňuje i úvahu o tom, že pokud shora uvedeným zpơsobem porušili povinnost řádně opatrovat nebo spravovat majetek obce, jde o porušení důležité povinnosti ve smyslu \255a odst. 1 tr. zák., resp. \ 221 odst. 1 TrZ. Zavinění z vědomé, resp. hrubé nedbalosti [ 5 písm. a) tr. zák., \16 odst. 1 písm. a), odst. 2 TrZ] by zde bylo možné dovodit u členů zastupitelstva obce mimo jiné např. i z toho, že na zasedání zastupitelstva obce, na němž se rozhodovalo o schválení prodeje nemovitého majetku obce, byli upozorněni jinými členy zastupitelstva obce na určité skutečnosti, z nichž vyplývá možnost př́liš nízké kupní ceny a které vědomě pominuli. Trestní odpovědnosti každého z členů zastupitelstva obce, který hlasoval 
pro schválení nevýhodného prodeje nemovitého majetku obce, pak nebrání ani skutečnost, jestliže rozhodoval jako člen kolektivního orgánu obce. Ke schválení prodeje nemovitého majetku obce se totiž vyžaduje souhlas nadpoloviční většiny všech členů zastupitelstva obce ( $\int 87 \mathrm{OZ}$ r) , takže všichni členové zastupitelstva představující tuto většinu, bylo-li jí dosaženo, se bezprostředně podíleli na přijetí takového rozhodnutí zastupitelstva obce, přičemž každý z nich měl stejný hlas. Proto i trestní odpovědnost za schválení a důsledky rozhodnutí přijatého zmíněnou většinou, pokud bylo učiněno v rozporu s povinností členů zastupitelstva obce řádně spravovat majetek obce ( 38 a násl. OŽr), mohou nést všichni členové zastupitelstva obce, kteři hlasovali pro schválení určitého rozhodnutí, jímž byla způsobena škoda na majetku obce.

Přestože i členové zastupitelstva obce (města) mohou mít obecně postavení úřední osoby ve smyslu \ 127 odst. 1 písm. d) TrZ, v tomto př́padě se vưbec neuvažovalo o možném souběhu s trestným činem zneužití pravomoci úřední osoby podle $\int 329 \operatorname{TrZ}$, protože všem obviněným členům zastupitelstva města se kladlo za vinu jednání jen z nedbalosti, zatímco zmíněný trestný čin vyžaduje úmyslné zavinění a ještě tzv. druhý úmysl (viz výše pod bodem 4.2).

\section{Rozdělení rozhodovacího procesu souvisejícího s hospodařením $\mathrm{s}$ veřejným majetkem $\mathrm{z}$ hlediska pravomoci}

Podle $\int 127$ odst. 1 písm. d) TrZ je úřední osobou člen zastupitelstva nebo odpovědný úředník územní samosprávy, orgánu státní správy nebo jiného orgánu veřejné moci, pokud plní úkoly státu nebo společnosti a používá při tom svěřené pravomoci pro plnění těchto úkolů. Kraji, hlavnímu městu Praze, obci, a tedy i příslušným úředním osobám, ustanovení \ 1 odst. 4, \2 odst. 3 KZřr, \ 2 odst. 2 ZHMP a \ 2 odst. 2 OŽr ukládají úkol pečovat o všestranný rozvoj svého území a o potřeby svých občanů a zároveň při plnění svých úkolů chránit též veřejný zájem. K plnění těchto úkolů je územním samosprávným celkům mimo jiné svěren veřejný majetek. K tomu lze poukázat na ustanovení \ 17 odst. 1 KZř, \ 35 odst. 1 ZHMP a \ 38 odst. 1 OŽr, která ukládají povinnost využívat majetek ÚSC účelně a hospodárně v souladu se zájmy ÚSC a s úkoly vyplývajícími z jeho působnosti vymezené zákonem, anebo na judikaturu Ústavního soudu, která se zabývala určitými otázkami hospodaření v rámci územní samosprávy. ${ }^{9}$ U státu lze obdobně odkázat na ustanovení \14 odst. 1 zákona č. 219/2000 Sb., o majetku České republiky a jejím vystupování v právních vztazích, ve znění pozdějších předpisů.

9 Viz nálezy Ústavního soudu ze dne 9. 7. 1996, sp. zn. II. ÚS 294/95, publikovaný pod č. 63 ve svazku 5 Sbírky nálezů a usnesení Ústavního soudu, a ze dne 20. 6. 2012, sp. zn. IV. ÚS 1167/11, publikovaný pod č. 123 ve svazku 65 Sbírky nálezů a usnesení Ústavního soudu, a též usnesení Ústavního soudu ze dne 26. 2. 2015, sp. zn. III. ÚS 2994/13. 
Rozhodovací proces ohledně veřejného majetku tak lze rozdělit na dvě části.

První z nich lze označit za část záměrovou. V této části rozhodovacího procesu se rozhoduje o tom, co konkrétně je současnými zájmy a úkoly společnosti či územního samosprávného celku, např. zř́zení školy, parku, postavení sociálních bytů apod. V této části procesu zásadně ekonomické úvahy nemají místo, naopak se zde při stanovení veřejného záměru uplatňují úvahy politické.

Teprve na základě takovéhoto autoritativního rozhodnutí o aktuálních a konkrétních zájmech a úkolech společnosti je následně za účelem jejich realizace nutné vynakládat majetek účelně a hospodárně, jak vyplývá z již výše zmíněných ustanovení $\int 17$ odst. $1 \mathrm{KZ}$ r̆, \ 35 odst. 1 ZHMP a \38 odst. 1 OŽ̌r. Tuto část lze označit jako část realizační, v rámci níž se teprve uplatňují mimo jiné kritéria hospodárnosti, účelnosti a efektivnosti (péče rádného hospodáře při dispozicích s veřejným majetkem).

Jak je vidět, právě rozhodnutí v záměrové části rozhodovacího procesu v sobě obsahuje prvek moci a prvek rozhodování. Jde totiž o pravomoc svěřenou zákonem konkrétním orgánům veřejnoprávní korporace [viz nap̌r. v př́padě obce $\int 85$ a \ 99 odst. 2 písm. a), $\mathrm{m})$, odst. $3 \mathrm{OZ}$ r] autoritativně rozhodovat o momentálních zájmech a úkolech státu a společnosti, př́padně rozhodovat o tom, které úkoly a zájmy státu a společnosti budou upřednostněny a realizovány z omezených veřejných prostředků. Tato část rozhodovacího procesu má tedy silný veřejnoprávní prvek.

Oproti tomu v rámci realizační části už jde svou podstatou o nakládání s cizím (veřejným) majetkem, při kterém je nutné jednat s péčí řádného hospodáře, zejména účelně, hospodárně a efektivně, a k výkonu pravomoci zde tedy zásadně již nedochází.

Přesto ke spáchání trestného činu zneužití pravomoci úřední osoby podle \329 TrZ může dojít ve specifických př́padech i při rozhodování v realizační části procesu v rámci toho, že se taková osoba podílí na výkonu rozhodnutí v záměrové části. Je tomu tak tehdy, pokud se prokáže pohnutka úřední osoby zneužít rozhodnutí v záměrové části ke způsobení škody či k získání neoprávněného prospěchu.

$\mathrm{V}$ praxi samozřejmě mnohdy nejsou tyto fáze rozhodovacího procesu od sebe viditelně odděleny, ale naopak bývají neoddělitelně spojeny do jednoho rozhodnutí. To platí např. tehdy, když se předkládá ke schválení autoritativní rozhodnutí o momentálním úkolu či zájmu státu a společnosti prostřednictvím dispozice s majetkem, a to společně se zpracovanou realizací této dispozice.

Lze tedy shrnout, že prvek moci a prvek rozhodování při dispozici s veřejným majetkem je obsažen v pravomoci úřední osoby nikoli vůči smluvním partnerům (dodavatelům, kupujícím apod.), ale vůči veřejnoprávní korporaci (ÚSC) a společnosti, jejímž jménem úřední osoba jedná nebo za kterou rozhoduje. 


\section{Některé dílčí závěry}

Přestože obsah výše citovaných i některých dalších rozhodnutí Nejvyššího soudu může vyvolávat určité pochybnosti o tom, zda a kdy př́slušné úřední osoby působící v oblasti územní samosprávy vykonávají nějakou pravomoc při dispozicích s veřejným majetkem, dospěli jsme k následujícím závěrům.

Ustanovení \127 odst. 1 TrZ, charakterizující výkon pravomoci úřední osoby, ji váže na plnění úkolů státu nebo společnosti. Tyto úkoly jsou v př́ípadě územních samosprávných celků vymezeny v ustanoveních \1 odst. 4, \2 odst. 3 KŽr, \ 2 odst. 2 ZHMP a $\int 2$ odst. 2 OŽr. Orgánům územní samosprávy byla v souvislosti s těmito úkoly svěřena pravomoc nakládat s veřejným majetkem územního samosprávného celku jakožto prostředek plnění úkolů státu nebo společnosti, jak to vyplývá zejména z ustanovení \} 1 7 \text { odst. } 1 \mathrm { KZ } \text { r̆, \ } 3 5 \text { odst. } 1 \text { ZHMP a \ } 3 8 \text { odst. } 1 \text { OZřr. V takových prrípadech je prvek } moci a prvek rozhodování obsažen $\mathrm{v}$ zákonném zmocnění určených úředních osob, aby rozhodovaly o momentálních zájmech a úkolech státu a společnosti prostřednictvím nakládání s veřejným majetkem a aby v tomto smyslu autoritativně měnily majetkové poměry územního samosprávného celku. Totéž lze přiměřeně konstatovat o úředních osobách působících v organizačních složkách státu.

Každý případ nakládání s veřejným majetkem je však třeba posuzovat individuálně podle konkrétních okolností a na podkladě příslušné právní úpravy. Nelze vycházet jen z formálního postavení úřední osoby, ale prrípadná trestná činnost musí vždy souviset s výkonem nějaké pravomoci úřední osoby, má-li být posouzena (též) jako trestný čin zneužití pravomoci úřední osoby podle $\int 329 \operatorname{Tr} Z .^{10}$

10 Některé další závěry $\mathrm{k}$ trestní odpovědnosti $\mathrm{v}$ oblasti územní samosprávy viz v publikaci PÚRY, $\mathrm{F}$. a M. RICHTER. Trestní odpovédnost v územni samosprávě. Komentovaná soudní roz̧hodnutí. Praha: C. H. Beck, 2017, 200 s. ISBN 978-80-7400-662-3. 